\title{
Zaburzenia osobowości jako przyczyna niezdolności konsensualnej do zawarcia małżeństwa kanonicznego
}

\begin{abstract}
Streszczenie
Opracowanie obejmuje analizę opinii psychologicznych wyjętych ze spraw dotyczących nieważności małżeństwa, które były procedowane i wyrokowane w Sądzie Biskupim Diecezji Toruńskiej. Przedstawia założenia teoretyczne, które mają charakter prawny odnoszący się do zaburzeń osobowości w psychologicznym wymiarze w odniesieniu do wyrażenia ważnej zgody na małżeństwo. Część teoretyczna pracy odwołuje się do instytucji zgody małżeńskiej, która jest przyczyną sprawczą małżeństwa, i ukazuje jej nieważność w aspekcie podmiotowym i przedmiotowym w oparciu o zaburzenia osobowości. W części badawczej dokonana analiza przedstawia zaburzenia osobowości powodujące nieważność małżeństw z rozróżnieniem na etiologię poszczególnych zaburzeń oraz obszar dysfunkcyjności wykazany przez powołanych biegłych sądowych w zakresie realizacji życia małżeńskiego i rodzinnego.
\end{abstract}

\section{Słowa kluczowe:}

nieważność małżeństwa, zaburzenia osobowości, przyczyny psychiczne, niezdolność konsensualna

1 Wiesław Kraiński, Wydział Teologiczny, Uniwersytet Mikołaja Kopernika w Toruniu, e-mail: krainskw@umk.pl, ORCID ID: https://orcid.org/0000-0002-6236-6652. 


\begin{abstract}
The following study encompasses the analysis of a range of psychological opinions extracted from marriage invalidation cases, which were proceeded by the Bishop's Court in the Diocese of Toruń. The article presents theoretical assumptions which are of legal nature and refer to personality disorders in psychological terms in the context of valid matrimonial consent. The theoretical part of the study refers to the institution of the matrimonial consent, which is the causative force of marriage and presents its invalidity in both subjective and objective aspect on the grounds of personality disorders. The analysis conducted in the research part presents various personality disorders contributing to the invalidation of marriage, distinguishing between the etiology of particular disorders and the dysfunctionality areas indicated by the appointed court experts in family and marital life.
\end{abstract}

\title{
Keywords:
}

marriage invalidation, personality disorders, psychic causes, consensual incapacity

\section{WPROWADZENIE}

Każde małżeństwo, nie tylko sakramentalne, zgodnie z doktryną katolicką ze swej natury jest nierozerwalne. Przyczyną sprawczą zaistnienia małżeństwa jest zgoda małżeńska, która jest aktem woli. Doktryna domaga się, aby był to akt osobowy, wyrażony zewnętrznie, wewnętrzny, wolny, z intencją aktualną lub wirtualną, bilateralny oraz nieodwołalny. W kontekście tematu musi to być również akt świadomy. Wśród przeszkód uniemożliwiających wyrażenie wolnej i świadomej zgody na małżeństwo są anomalie psychiczne (Chiappetta, 1990, s. 33).

Zgodnie z normą kan. 1057 § 2 KPK (Kodeks Prawa Kanonicznego) zgoda jest aktem woli. Akt woli w swej strukturze musi być działaniem przemyślanym oraz chcianym, ponadto należy do władz duchowych człowieka. Akt woli w wyrażaniu zgody ma małżeństwo może zostać ograniczony wskutek zaburzeń psychicznych. W procesach o stwierdzenie małżeństwa biegli w dziedzinie psychiatrii i psychologii klinicznej wyszczególniają zaburzenia osobowości. Istotą tegoż stwierdzenia nieważności małżeństwa jest wykazanie, że małżeństwo nie zaistniało wskutek przyczyny psychicznej - ex tunc w odróżnieniu od unieważnienia małżeństwa w chwili wydania orzeczenia - ex nunc.

W corocznych sprawozdaniach trybunałów kościelnych do Sygnatury Apostolskiej w Rzymie wylicza się tytuły nieważności spraw, ale w zakresie kanonicznym. 1095 KPK - niezdolności o charakterze psychicznym nie specyfikuje się rodzaju 
zaburzeń. Przedstawienie i opis poszczególnych zaburzeń osobowości na podstawie akt spraw Sądu Biskupiego Diecezji Toruńskiej - SBDT z lat 2006-2016² stwarza poglądowe, choć nie statystyczne, ujęcie sprawy.

Wojciech Góralski wprowadza rozróżnienie na niezdolność konsensualną podmiotową, o której mówi kan. 1095 KPK - n. 1 „Niezdolnymi do zawarcia małżeństwa są ci, którzy pozbawienia są wystarczającego używania rozumu”, n. 2 „mają poważny brak rozeznania oceniającego co do istotnych obowiązków i praw małżeńskich”. W przypadku niezdolności konsensualnej podmiotowej zgoda staję się nieważna w sposób bezpośredni podczas wyrażania aktu woli. W przypadku niezdolności konsensualnej podmiotowej mamy do czynienia z brakiem zdolności oceniającej (Góralski, 1996, s. 36-41). Niezdolność konsensualna przedmiotowa n. 3 „są niezdolni z przyczyn natury psychicznej do podjęcia istotnych obowiązków małżeńskich” - ma charakter niezdolności wykonawczej. Kontrahent jest zdolny do wyrażenia zgody małżeńskiej, ale z przyczyn natury psychicznej nie jest w stanie wypełnić jej przedmiotu, czyli podjąć się istotnych obowiązków małżeńskich, które przynależą do powziętej zgody (Góralski, 1996, s. 36-41). Zarówno niezdolność konsensualną podmiotową, jak i przedmiotową ograniczają zaburzenia osobowości.

\section{ZABURZENIA OSOBOWOŚCI OGRANICZAJĄCE ZDOLNOŚĆ KONSENSUALNĄ PODMIOTOWĄ W AKTACH SBDT}

Zaburzenia osobowości związane z niezdolnością konsensualną podmiotową, o której mówi kanon 1095 no. 2 - wyróżnione przez biegłych SBDT - które wpływają na brak rozeznania oceniającego, można wyszczególnić według grup zaburzeń osobowościowych. Sprawy sądowe tej kategorii nieważności są nieliczne i można je zilustrować.

Osobowość dyssocjalna o charakterze agresywnym. Osobowość ta miała swój początek w rodzinie pierwotnej pozwanego i w jego wychowaniu. Pozwany pochodzi z rodziny, gdzie panowały patologiczne wzorce: ojciec był alkoholikiem i stosował przemoc wobec matki, nie szanował jej. Taki model traktowania żony pozwany przejął od swojego ojca i naśladował w związku stron (władczość, apodyktyczność, próba podporządkowania sobie żony przez przemoc słowną, manipulację i agresję fizyczną). Pozwany nie był nauczony w tej rodzinie odpo-

${ }^{2}$ Opracowanie autora bazuje i przedstawia wyniki jego pracy magisterskiej z zakresu psychologii klinicznej i zdrowia na SWPS w Warszawie w 2018 roku. 
wiedzialności i obowiązkowości (wyręczała go matka i rodzeństwo). Zaburzenie osobowości antyspołeczne skutkowało poważnym brakiem rozeznania instytucji małżeństwa, zwłaszcza obowiązku wobec potomstwa, co potwierdził zespół sędziowski wyrokiem za nieważnością małżeństwa (Akta SBDT 46/P/08).

Osobowość histrioniczna. Mężczyzna w momencie zawierania sakramentu małżeństwa charakteryzował się osobowością histrioniczną (F.60.4). Biegła wymieniła w opinii symptomy: płytka ekspresja emocji, uczucie dyskomfortu w sytuacjach społecznych - nieznaczny lęk w relacjach interpersonalnych; silna potrzeba bycia zauważonym; wycofanie i znaczne trudności w otwieraniu się na relacje interpersonalne; uciekanie w świat nierealny lub powierzchowne kontakty z innymi; podejmowanie decyzji w sposób niedojrzały, a także egoistyczny; silne poczucie odrębności i własności jako sposób na budowanie wartości własnej.

Zgodnie z aktami sprawy osobowość niedojrzała o cechach histrionicznych ukształtowała się w pozwanym pod wpływem sytuacji rodzinnej. Jak zeznają strony oraz świadkowie, pozwany stracił matkę, mając 6 lat. Ojciec nie zadbał emocjonalnie o pozwanego i związał się z kobietą, wobec której był uległy, pozwalał emocjonalnie odrzucać pozwanego. Pozwany uciekał z domu do starszej siostry. Sytuacja trwająca przez cały okres młodości pozwanego spowodowała w nim powstanie deficytów w podstawowych obszarach - bezpieczeństwa, miłości, wsparcia, uznania, przynależności, co również skutkowało brakiem rozeznania walorów instytucji małżeństwa w chwili jego zawierania (Akta SBDT 52/P/10).

Osobowość narcystyczna. Biegli opisują osoby z osobowością narcystyczną jako nieodpowiedzialne, niekonsekwentne w podejmowanych działaniach i decyzjach, stosujące niedojrzałe mechanizmy w zachowaniu, takie jak: manipulacje, obwinianie, histerię, agresję słowną, karanie milczeniem (Akta SBDT 12/P/12).

Powołany w spawie biegły sądowy wyszczególnił u mężczyzny przyczynę psychiczną w postaci znacznej niedojrzałości z cechami osobowości narcystycznej. Przyczyna ta skutkowała:

- poważnym brakiem rozeznania oceniającego co do istotnych praw i obowiązków małżeńskich;

- brakiem zdolności do podjęcia istotnych obowiązków małżeńskich.

Biegły wyszczególnia obszary zaburzonego funkcjonowania pozwanego: brak inicjatywy w obszarze zawodowym, podejmowania decyzji, kłamstwo, oszukiwanie, manipulacja, wykorzystywanie innych w sprawach finansowych, bierność i zachowania ucieczkowe w wyborach życiowych, wielkościowe poczucie „ja”, egocentryzm i nieadekwatna ocena siebie, nadużywanie alkoholu w stopniu znacznym. Nieprawidłowości w osobowości pojawiły się u pozwanego w okresie dojrzewania (Akta SBDT 12/P/12). 
Tendencje osobowościowe o charakterze narcystycznym występujące u jednej z pozwanych spowodowały niepełne rozeznanie oceniające co do istoty sakramentu małżeństwa: pozwana nie zdawała sobie sprawy z wagi sakramentu małżeństwa, a ślub kościelny zawarła jedynie dlatego, by mieć wymarzone mieszkanie, a wcześniej uzyskać na nie kredyt, chciała też mieć piękny i widowiskowy ślub (Akta SBDT 58/P/13).

Osobowość narcystyczna wpływa poważnie na zdolność oceny krytycznej i rozeznanie istotnych obowiązków małżeńskich. Dla kontrahentów tej kategorii prawa i obowiązki małżeńskie nie mają żadnego znaczenia, wynika to z nieodpowiedzialności i skrajnych postaci egoizmu.

Osobowość z pogranicza. W fazie decyzyjnej małżeństwa, wskutek osobowości zaburzonej typu borderline, istnieje poważny brak rozeznania oceniającego, zwłaszcza w kwestii wierności małżeńskiej. Struktura osobowości u tych osób jest zaburzona na tyle, że nie potrafią ocenić krytycznie, czym jest wspólnota życia małżeńskiego według badanego materiału w zakresie wierności.

Biegły sądowy wyszczególnił przyczynę psychiczną, która uniemożliwiła pozwanej wypełnienie obowiązków małżeńskich i zakłóciła rozeznanie oceniające. W dorosłe życie wchodziła obciążona poważnymi deficytami w zakresie dbania o siebie, sfery tożsamości i zdolności do tworzenia trwałych i stabilnych związków. Wykazywała problemy w poszanowaniu swojej intymności (kontakty z wieloma mężczyznami w trakcie pozostawania w związku z powodem), ustalenia i ochrony swoich granic psychologicznych i relacji z drugim człowiekiem. Pozwaną cechował promiskuityzm (kontakty seksualne pozbawione więzi uczuciowych, podejmowane z przypadkowymi, zmienianymi partnerami oraz nieumiejętność utrzymania trwałych związków). Wyniki badań psychologicznych oraz dokładna analiza faktów z życia pozwanej wskazują, iż reprezentowała ona zaburzenie borderline - typ pograniczny, co skutkowało poważnym brakiem rozeznania oceniającego odnośnie do istotnych praw i obowiązków małżeńskich (Akta SBDT 12/P/11).

Jak wynika z akt sprawy analizy zachowań w momencie zawierania i w trakcie związku małżeńskiego osób, które charakteryzowały się osobowością borderline F.60.31, ta osobowość dominuje w sferach życia jako wzorzec niestabilności w relacjach międzyludzkich, autoidentyfikacji i uczuciach, a także znacznej patologicznej impulsywności. Osoby cierpiące na to zaburzenie charakteryzują się brakiem rozeznania oceniającego w zakresie obowiązków i w konsekwencji niezdolnością konsensualną podmiotową (Akta SBDT 29/P/14).

Osobowość zależna. Biegli wymieniają istotne cechy, które wpłynęły na poważny brak rozeznania oceniającego u kontrahentów z osobowością zależną: nieznajomość siebie i swoich potrzeb, mały wgląd w siebie, nieznajomość osoby 
powoda; lęk społeczny przed staropanieństwem, niedojrzałość z racji wieku, narcyzm, emocjonalna zależność od osób znaczących, niesamodzielność w podejmowaniu decyzji życiowych, problemy z określeniem własnych potrzeb, hierarchii wartości, celów życiowych spójnych z tożsamością - wewnętrzne zamieszanie, brak właściwej integracji psychoemocjonalnej, niedojrzałe rozumienie małżeństwa (Akta SBDT 18/P/15).

W przypadku ciężkości defektu rozeznania oceniającego, który jest kategorią prawną opartą o kryteria medyczne, biegli w opiniach określają i wskazują na defekt rozeznania, stwierdzając: „Powódka przeżywała nieuświadomiony konflikt wewnętrzny (z jednej strony miała inne priorytety życiowe niż zakładanie rodziny chciała studiować, podróżować, rozwijać swoje hobby, spotykać się ze znajomymi, a pozwanego traktowała jak sympatię, ale nie przyszłego męża”. Z drugiej strony powódka podjęła decyzję o małżeństwie na skutek propozycji pozwanego i jego rodziców (wybudowali dom dla stron i chcieli by strony tam zamieszkały). Powódka prezentowała postawę uległą - nie wyrażała jasno swojego zdania (tego, że nie chce mieszkać na wsi z pozwanym, że nie chce jeszcze ślubu z nim), powódka zwodziła pozwanego - chciała odwlec datę ślubu. Inne cechy, którymi charakteryzowała się powódka w dniu ślubu, a które ujawnił test psychologiczny: stawia sobie nierealistyczne cele i oczekiwania w kontaktach z innymi, ma wątpliwości co do swojej roli kobiecej, jest niedojrzała - submisyjna, może wahać się między zachowaniami poddania się a zbuntowania, niedojrzała - nie bierze odpowiedzialności za swoje wybory, zachowania, cechują ją nieufność i ostrożność w relacjach ma trudności z otwieraniem się, wykazuje potrzebę społecznej aprobaty (Akta SBDT 24/P/14).

Biegli zwracają również uwagę na brak zdolności do wolnych samodzielnych decyzji, co także skutkuje niezdolnością konsensualną podmiotową. Osobowość strony powodowej w dniu ślubu charakteryzowała się znaczną niedojrzałością. Przeżycia z dzieciństwa (presja psychiczna, a także szantaż psychiczny ze strony matki, agresja fizyczna ojca wobec powódki - szarpanie, popychanie) wpłynęły na ukształtowanie się osobowości z kręgu lękowych - powódka charakteryzowała się w dniu ślubu osobowością lękową, nerwicą lękową z elementami depresji. Powódka znajdowała się pod silnym wpływem swojej matki od wczesnych lat dziecinnych - była uzależniona od matki w sensie psychoemocjonalnym - matka wywierała wpływ na powódkę w decyzjach i postępowaniu. Cechy i zachowania charakterystyczne dla powódki w momencie zawierania małżeństwa: nadwrażliwość na odrzucenie i ocenę jej osoby przez innych; napięcie, roztrzęsienie, kontrola; nieufność i ostrożność w relacjach; introwersja społeczne; wyobcowanie od samej siebie, skrajnie niska samoocena, epizody depresji z objawami płaczliwości, braku sił, anhedonia; problemy podczas współżycia - zacisk pochwy, napięcie, 
lęk, trudności z przeżywaniem satysfakcji seksualnej (Akta SBDT 44/P/14). Defekt psychiczny - uzależnienie (od matki) - ma charakter osobowości zależnej istniejącej w chwili zawarcia małżeństwa, a kształtował się on już w dzieciństwie. Przyczyna psychiczna była tak silna, że powódka nie zdawała sobie sprawy, czym jest małżeństwo, nie była w stanie stworzyć wspólnoty życia z małżonkiem. Małżeństwo to było swoistym trójkątem: matka-mąż-powódka, która była z tego tytułu poddawana terapii (Akta SBDT 28/P/14).

Przyczyna nieważności małżeństwa z normy kan. 1095 n.2 w obrocie sądowym nie jest częsta. Sami biegli wykazują rodzaj zaburzenia kontrahenta, wskazując w opiniach na trudność określenia stopnia zaburzenia, który ograniczałby zdolność rozeznania i krytycznej oceny w chwili zawierania małżeństwa.

\section{ZABURZENIA OSOBOWOŚCI OGRANICZAJĄCE ZDOLNOŚĆ KONSENSUALNĄ PRZEDMIOTOWĄ W AKTACH SBDT}

Niezdolność konsensualna przedmiotowa, o której norma kan. 1095 n. 3, odnosi się bezpośrednio do przyczyn natury psychicznej ob gravem anomalium psychicam. Przyczyny natury psychicznej są sformułowaniem bardzo pojemnym, zawierają w sobie anomalie psychiczne, takie jak: choroby psychiczne, zaburzenia osobowości, dysfunkcje seksualne (Chiappetta, 1990, s. 205-209, Zuanazzi, 2013).

Kryteria wypracowane przez doktrynę i jurysprudencję w ocenie niezdolności w obrębie kanonu 1095 n.3 KPK: niezdolność musi być pewna - certa; ciężka grave; trwała - perpetua; uprzednia - antecedente (Chiappetta, 1990, s. 210-221). Niezdolność, która jest przyczyną nieważności małżeństwa, odnosi się zawsze do capacitas adimplendi obligationes - obowiązków małżeńskich, dobra potomstwa, dobra wierności, zdolności do trwania w małżeństwie nierozerwalnym, dobra małżonków, wzajemnego przekazu i przyjęcia w celu stworzenia permanentnej wspólnoty życia małżeńskiego (Amati, 2009, s. 147-149).

Podstawą do orzeczenia nieważności małżeństwa z przyczyn natury psychicznej musi być rzeczywista niezdolność, nie zaś trudność, którą kontrahenci są wstanie pokonać własnym wysiłkiem, np. terapią (Erlebach, 2004, s. 206-207).

Opis zaburzeń osobowości powodujących niezdolność do podjęcia istotnych obowiązków małżeńskich zgodnie z tonem sądownictwa kościelnego należy przedstawić według klasyfikacji DSM-5. Na założenia Amerykańskiego Towarzystwa Psychiatrycznego powołuje się jurysprudencja Roty Rzymskiej, która wytycza szlaki interpretacyjne dla innych trybunałów kościelnych. DSM w związku z podobieństwem objawów i cech zburzeń osobowości wyróżnia trzy grupy: A - grupa 
dziwaczna lub ekscentryczna; B - grupa dramatyczna; C - grupa lękowa, bojaźliwa (Cześnikewicz, 2017, s. 390). Wyszczególniając cechy charakterystyczne dla danego zaburzenia osobowości, należy zwrócić uwagę na etiologię zaburzenia, gdyż tylko obecność zaburzenia w chwili wyrażania zgody na małżeństwo ma odniesienie do jego nieważności. Następnym aspektem skutkującym nieważnością konsensualną przedmiotową jest istnienie rzeczywistego zaburzenia, a nie wyłącznie rysu zaburzenia. Wreszcie należy wskazać na obszar dysfunkcyjny, który ma odniesienie do obowiązków małżeńskich. W celu ukazania trudności diagnostycznych w każdym z przedstawionych zaburzeń osobowości z opinii biegłych należy wyszczególnić rozpoznanie różnicowe. Szerokie spektrum rozpoznania różnicowego jest zgodne z brzmieniem ustawy kanonicznej kan. 1095 nr 3 - „z przyczyn natury psychicznej” i daje zarówno biegłym, jak i sędziom możliwość szerokiej oceny niezdolności. Analiza zaburzeń osobowości dokonana jest w oparciu nie tyle o literaturę przedmiotu, ile o akta spraw sądowych SBDT.

Pierwsza grupa to zaburzenia osobowości typu A - zaburzenia dziwaczno-ekscentryczne. W jej spektrum mieści się paranoiczne zaburzenie osobowości 301. 0 (F 60.0). Metaforyczne określenie osobowości „Nie ufaj nikomu” (Cześnikewicz, 2017, s. 390). Etiologią osobowości zaburzonej jest istnienie choroby psychicznej (Akta SBDT 11/P/11). Biegły po analizie akt i wywiadzie z powodem stwierdził: „U strony pozwanej w momencie zawarcia małżeństwa mogły istnieć objawy choroby psychiatrycznej - rozpoznanej przez lekarzy psychiatrów podczas leczenia syna stron (chorego na schizofrenię) jako schizofrenię paranoidalną (F20.0) lub zespół paranoidalny”. W chwili zawarcia małżeństwa ocena krytyczna u strony pozwanej w odniesieniu do przyszłego małżeństwa była zaburzona w stopniu znacznym, z powodu stanu psychicznego i psychiatrycznego. Z dostępnego materiału wynika, że zaburzone zachowanie pozwanej miało znaczny wpływ na rozumienie i podjęcie przez nią istotnych obowiązków małżeńskich.

Biegli sądowi sporządzili opinię psychologiczną na podstawie zebranej dokumentacji oraz wywiadu ze stronami i stwierdzili, że obszar dysfunkcyjny obejmuje:

- dziwaczne i nieadekwatne zachowania;

- bezpodstawne oskarżanie, bicie i znęcanie się;

- pisanie listów do wyimaginowanych osób (np. prezydenta);

- podejrzenie, że ludzie zazdroszczą jej pieniędzy, urody, mądrości;

- poczucie, że jest najmądrzejsza, lepsza, najpiękniejsza, wyjątkowa;

- brak poczucia winy, współczucia, empatii odnośnie do swojego zachowania.

Oprócz powyższych symptomów we wszystkich opiniach pojawiała się nieufność do ludzi; nadwrażliwość na krytykę i reagowanie na nią atakiem, złością, zamykaniem się i odrzuceniem, zamiast podjęcia dialogu; sztywne mechanizmy 
przystosowania w kontaktach interpersonalnych (kontrola, manipulacja i sterowanie kontaktami bądź ucieczka); silny lęk społeczny; podejrzliwość i ideacje paranoidalne (silne subiektywne odczucia sugerujące, że inni są przeciwko niej lub ją krzywdzą - poczucie, że powód ją zdradza, a inni mogą otruć); sztywność w zachowaniu i poglądach; poczucie misji i wyjątkowości (np. pozwana chciała być adwokatem i ratować pokrzywdzonych ludzi - nazywała to swoją misją) (Akta SBDT 21/P/11). Osoby o takim zaburzeniu charakteryzowały się niezdolnością psychiczną i psychiatryczną w stopniu znacznym do podjęcia istotnych obowiązków małżeńskich. Przyczyna psychiczna, której obecność stwierdza biegły sądowy, ma swoją ciężkość kanoniczną, wskazuje na niezdolność do podjęcia istotnych obowiązków małżeńskich i stworzenia wspólnoty życia. Opinia biegłych w poszczególnych przypadkach znajduje potwierdzenie w literaturze psychologicznej (Gałecki, Pilecki, Romaszewska, Szulc, Sidorowicz, Wciórka, s. 109-113). Biegli w analizowanych opiniach w typie zaburzenia paranoicznego nie wyróżnili rozpoznania różnicowego. W grupie A wyróżniamy schizoidalne zaburzenie osobowości 301.20 (F 60.1). Metaforyczne określenie osobowości: „Możesz pukać, ale nikogo i tak nie zastaniesz” (Cześnikiewicz, s. 393). W analizie akt SBDT biegli wyszczególnili czystą postać osobowości schizoidalnej, ale również postać różnicową, gdzie schizoidalne zaburzenie osobowości, obecne z osobowością unikającą (Akta SBDT 39/P/11, 16/P/13) oraz w sprawach (Akta SBDT 25/P/11, 28/P/14) z osobowością niedojrzałą, a także nerwicą lękowo-depresyjną.

W żadnej ze spraw dotyczących zaburzenia osobowości schizoidalnej biegli nie opisali etiologii zaburzenia. Co zgodne jest z nielicznymi wynikami badań naukowych o podstawach genetycznych czy środowiskowych wyniesionych z dzieciństwa (Cześnikiewicz, s. 394).

W obszarze dysfunkcyjnym w jednym przypadku stwierdzono brak komunikacji w małżeństwie (Akta SBDT 25/P/11). W innych przypadkach biegli nie odnoszą się do analizy osobowości, a jedynie do stwierdzenia: „[...] pozwana charakteryzuje się cechami osobowości schizoidalnej (unikowo-schizoidalnej)” (Akta SBDT 28/P/14). Biegła sądowa orzekła również, że pozwana miała znaczne trudności w wypełnianiu obowiązków małżeńskich z powodu niedojrzałych postaw w zachowaniu i podejściu do małżeństwa.

Schizotypowe zaburzenie osobowości 301.22 (F 21) jest trzecim należącym do grupy A. Metaforyczne określenie osobowości to: „Jestem dziwaczny, inny, obcy” (Cześnikiewicz, s. 409).

Zaburzenie schizotypowe w sprawie (Akta SBDT 351/P/09) połączone z nerwicą lękową, elementami osobowości schizoidalnej, unikającej i uzależnieniem od hazardu; w sprawie (Akta SBDT 38/P/11) połączone z osobowością niedojrzałą 
schizoidalną oraz unikającą; w sprawie (Akta SBDT 1/III/14) - w łączności z osobowością schizoidalną oraz cechami syndromu DDA (dorosłe dzieci alkoholików). Syndrom DDA ma związek, zdaniem biegłego, z zaburzeniem osobowości schizotypowej. U strony powodowej istniała przyczyna psychiczna, co zostało udowodnione na podstawie analizy psychologicznej dokonanej przez trybunały trzech instancji, a zwłaszcza biegłego sądowego sądu trzeciej instancji. Biegły sądowy, opierając swoje wnioski o akta sprawy pierwszej z drugiej instancji oraz na wywiadzie ze stroną pozwaną, ponieważ powód nie stawił się do biegłego (Akta SBDT 1/III/14), wyróżnia osobowość powoda w momencie zawierania małżeństwa jako schizoidalno-schizotypową (F 60.6). Przeżycia z dzieciństwa, alkoholizm ojca, agresja fizyczna wobec matki i dzieci ukształtowały osobowość z kręgu unikowo-lękowych. DDA jest to współuzależnienie, które należy traktować jako chorobę oraz zaburzenie racjonalnego zachowania i myślenia. DDA sprawia, że osoby charakteryzują się podwójną tożsamością.

W wykazie obszarów dysfunkcyjnych sprawy (Akta SBDT 14/III/14, 38/P/11) takie osoby odznaczają się chłodem emocjonalnym, spłyceniem uczuciowości, ograniczona jest ich zdolność do wyrażenia uczuć przyjemnych, ciepłych, pojawia się chęć izolacji, podwyższony poziom lęku w relacjach wynikających z poczucia, że będzie się poddanym ocenie i odrzuconym, co powoduje, że te relacje są nieprawidłowe. Nadużywanie alkoholu podczas małżeństwa jest formą radzenia sobie z zaburzeniem.

Zaburzenia osobowości typu B - zaburzenia dramatyczno-niekonsekwentne należy do bardzo licznych w obrocie procesowo-psychologicznej. Pierwszym należącym do tejże grupy jest antyspołeczne zaburzenie osobowości 301.7 (F 60.2). Metaforyczne określenie osobowości: „Zrobię, co zechcę, i kiedy zechcę” (Cześnikiewicz, s. 395).

W łączności z osobowością antyspołeczną biegli wyróżnili: uzależnienie od alkoholu (Akta SBDT 9/P/12, 27/P/10), osobowość narcystyczną (Akta SBDT 8/P/11, 14/P/11, 38/P/14, 586/P/13), osobowość niedojrzałą (Akta SBDT 40/P/11, 36/P/13, 29/P/12, 32/P/12, 7/P/13, 11/P/13, 22/P/13, 1P/13, 49/P/14), osobowość histrioniczną (Akta SBDT 49/P/10), opóźnienie intelektualne, promiskuityzm, uzależnienie od hazardu, (Akta SBDT 42/P/13, 39/P/15, 1/P/14), agresję (Akta SBDT 25/P/14), kradzież (Akta SBDT 7/P/14), uzależnienie od narkotyków (Akta SBDT 60/P/13), homoseksualizm powiązany z osobowością dyssocjalną (Akta SBDT 14/P/14) oraz dysfunkcyjność w obszarze seksualnym (Akta SBDT 59/P/14).

Biegli upatrują etiologii zaburzenia osobowości antyspołecznej w rodzinie generacyjnej (Akta SBDT 21/P/12). Czas formowania się zaburzenia dyssocjalnego (F 60.2) dotyczy wczesnego dzieciństwa. Wśród etiologii osobowości dyssocjalnej 
wybija się rodzina generacyjna i stosowany model wychowawczy (Akta SBDT 32/P/12). Rodzice nie stawiają granic i wymogów wychowawczych, przyzwalają na niemoralne życie, kłamstwa (Akta SBDT 26/P/12). Znaczenie ma również pochodzenie z rodziny o niewłaściwych wzorcach religijnych, wychowawczych (np. ojciec pozwanego odszedł do innej kobiety od matki pozwanego, gdy pozwany miał kilka lat. Od 5-6 roku życia pozwanego wychowywała babcia, gdyż matka nie była w stanie poradzić sobie sama z wychowaniem dwóch synów. Pozwanego z matką łączyła bardzo niestabilna relacja - pełna kłótni i nieporozumień). Kolejną przyczyną jest patologiczna więź z rodzicami (Akta SBDT 50/P/13), którzy są niezdolni wychowawczo - zdrady rodziców (Akta SBDT 54/P/12). Wśród przyczyn osobowości dyssocjalnej w zakresie rodziny pierwotnej występuje również nadopiekuńczość matki (Akta SBDT 649/P/14). Na kształtowanie się osobowości pozwanej wpływ miała rodzina pierwotna. Matka pozwanej była osobą skrajnie nadopiekuńczą - rodzice, zarówno matka, jak i ojciec, robili wszystko za dzieci: dzieci nie miały żadnych obowiązków, a były wyręczane we wszystkim. Pozwana i jej bracia mogli robić to, co chcieli (zabawa, wczesne kontakty seksualne, upijanie się w wieku młodzieńczym) (Akta SBDT 586/P/13). W jednym przypadku biegły wyciąga wniosek, że osobowość dyssocjalna ma podstawy zawiązane z psychozą padaczkową (Akta SBDT 62/P/14).

Etiologia osobowości antyspołecznej, zdaniem biegłych, ma swoje podłoże w rodzinie proalkoholowej. Na ukształtowanie się takiej osobowości będzie wpływał alkoholizm w rodzinie o charakterze patologicznym (Akta SBDT 4/P/13, 35/P/11, 46/P/09), model traktowania matki przez ojca, brak szacunku, stosowanie przez ojca przemocy wobec matki (w sensie psychicznym i fizycznym), często problemy ojca z prawem (Akta SBDT 18/P/11). Biegły wskazał, że na tworzenie osobowości antysocjalnej mają wpływ relacje rodzinne - u mężczyzny, który stracił rodziców w wieku 4 lat i był wychowany w domu dziecka, brak więzi z rodziną sprawił, że nie był w stanie funkcjonować w małżeństwie i społeczeństwie (Akta SBDT 11/P/12).

Zaburzenie osobowości antyspołeczne przyjmuje różne postacie dysfunkcyjne. Wyróżniono osobowość o charakterze agresywnym (Akta SBDT 46/P/08), u której dominowała władczość, agresywność, próba całkowitego podporządkowania, przemoc i agresja fizyczna - co skutkowało dysfunkcją w obszarze życia rodzinnego. Obszar życia rodzinnego przenosi się na grunt problemów z prawem, braku empatii, manipulacji, brakiem poszanowania praw innych, brakiem odpowiedzialności za czyny, mściwością, zastraszaniem, kontrolowaniem bliskich, brakiem poczucia winy (Akta SBDT 18/P/11), wyłudzaniem pieniędzy, zaciąganiem kredytów, uprawianiem hazardu, przymuszaniem do współżycia, wyżywaniem się na przedmiotach martwych, niedotrzymywaniem zobowiązań 
finansowych, funkcjonowaniem poza życiem rodzinnym w kręgu: koledzy-alkohol (Akta SBDT 1 III/P/11).

W obszarze dysfunkcyjnym biegli wskazywali również na zaburzenia dyssocjalne osobowości, bunt wobec przyjętych społecznie autorytetów, na przykład matki, oraz impulsywność w sferze seksualnej, niewierność partnerów, kłamstwo, kłótnie, rękoczyny, kradzież (Akta SBDT 10/P/12). Biegli wskazują na mściwość, nadużywanie alkoholu, wyższość, chorobliwą zazdrość, nieodpowiedzialność w zakresie zawodowym, patologiczne podejście do pieniędzy (Akta SBDT 13/P/12). Biegła zwraca uwagę również na powiązanie cech osobowości dyssocjalnej z niedojrzałością - uzależnienie od narkotyków typu marihuana i amfetamina, łamanie prawa, nadużywanie alkoholu (Akta SBDT 51/P/13, 29/P/12).

Zaburzenie antyspołeczne osobowości, jak wykazują biegli, przejawia się w następujących obszarach życia:

- obszarze edukacji, podczas której pozwany miał problemy z zachowaniem (bójki, używanie narkotyków, nadzór kuratora);

- obszarze zawodowym - z powodu niestabilności i braku konsekwencji pozwany podejmował różne prace zawodowe, zwalniał się z nich, wchodził w konflikty z pracodawcami, miał problemy z podjęciem obowiązków jako pracownik;

- obszarze uzależnień - akta sprawy wskazują na to, że pozwany był uzależniony od narkotyków już w okresie przedślubnym. Jak stwierdza biegły, objawami uzależnienia były: przekrwione oczy, nadpobudliwość psychomotoryczna, stany depresyjne, myśli samobójcze, apatia, bierność, lęki, bezsenność lub nadmiar snu, agresja słowna i fizyczna, urojenia prześladowcze, podejrzliwość (Akta SBDT 40/P/10);

- obszarze społecznym - pozwany prowadził życie kawalerskie, bez zobowiązań. Biegły diagnozuje przyczynę i określa jej stopień jako umiarkowany, ale biorąc pod uwagę całość materiału dowodowego, należy stwierdzić, że przyczyna jest ciężka i w sposób poważny zakłóciła zdolność pozwanego do zbudowania trwałej wspólnoty małżeńskiej (Akta SBDT 40/P/10). Osobowości dyssocjalnej towarzyszy niedojrzałość, kłamstwo, życie bez zobowiązań, poniżanie innych, manipulacja, kłótliwość, rozchwianie seksualne, brak poczucia winy (Akta SBDT 26/P/12), agresja fizyczna, przemoc psychiczna, oszukiwanie dla zysku, egocentryzm, egoizm, brak poczucia winy, impulsywność w sferze seksualnej, przywłaszczenie mienia (Akta SBDT 53/P/12).

Wśród badanych spraw biegli wyróżnili, oprócz wcześniej wspomnianych cech osobowości dyssocjalnej, uzależnienie od seksu (Akta SBDT 26/P/11). Pozwany - 
mężczyzna - chwali się licznymi relacjami seksualnymi, nadużyciami w sferze seksualnej. Biegli łączą zaburzoną osobowością o charakterze dyssocjalnym (F 60.2) oraz narcystyczną (F.60.8), a także nadmierny popęd/uzależnienie seksualne (F 52.7) (Akta SBDT 14/P/11). W jednej ze spraw biegły dokonuje szczegółowego opisu konkretnych symptomów zaburzenia pozwanego, są to: impulsywność w obszarze seksualnym (liczne zdrady i związki seksualne), napady agresji słownej oraz fizycznej, poniżanie, krytykowanie, wypadki samochodowe po spożyciu alkoholu, brak odpowiedzialności w sprawach zawodowych i rodzinnych, brak uczucia winy, egoizm, egocentryzm, manipulowanie w celu osiągnięcia swoich celów, praktykowanie seksu grupowego, oralnego, używanie gadżetów seksualnych i przymuszanie partnerek do tego samego, regularne oglądanie filmów pornograficznych, onanizowanie się, gwałt na powódce, gdy odmawiała seksu, masturbacja jako sposób na wyładowanie swoich emocji, nieumiejętność odroczenia współżycia seksualnego i zapanowania nad nim, płacenie studentkom za seks, molestowanie seksualne studentek - namawianie do seksu w zamian za zaliczanie egzaminów (Akta SBDT 24/P/12).

Biegli wskazują również na powiązanie osobowości antysocjalnej z uzależnieniem od hazardu (Akta SBDT 37/P/12). Osobowość pozwanego charakteryzuje się: osobowością zaburzoną dyssocjalną (F 60.2 według DSM -V) oraz uzależnieniem od hazardu (F 263.0. według DSM-IV). Obszar dysfunkcyjny w opisie osobowości dyssocjalnej określa się jako kierowanie się tylko względami materialnymi (Akta SBDT $50 / \mathrm{P} / 13)$.

Kolejnym zaburzeniem w grupie B jest histrioniczne zaburzenie osobowości: 301.50 (F 60.4). Metaforyczne określenie osobowości: „Skup na mnie całą swoją uwagę" (Cześnikiewicz, s. 399).

W rozpoznaniu różnicowym osobowość histrioniczna łączona jest z niedojrzałością psychoemocjonalną (Akta SBDT 36/P/11, 52/P/10, 47/P/14), z osobowością obsesyjno-kompulsywną (Akta SBDT 48/P/12, - 36/P/12, 49/P/10, 28/P/13, 7/P/12), z osobowością zależną (Akta SBDT 53/P/14, 4/P/14), z cechami osobowości narcystycznej (Akta SBDT 40/P/13) oraz z zaburzeniem bordeline (Akta SBDT 30/P/14).

Biegli wskazują w etiologii zaburzenia na sytuację rodzinną i związane z nią deficyty (Akta SBDT 52/P/10). Akta sprawy pokazują, że osobowość niedojrzała o cechach histrionicznych ukształtowała się w pozwanym pod wpływem sytuacji rodzinnej. Jak zeznają strony oraz świadkowie, pozwany jako dziecko stracił matkę. Ojciec nie zadbał emocjonalnie o jego prawidłowy rozwój i poczucie bezpieczeństwa. Ta długotrwała sytuacja wywołał niezdolność konsensualną przedmiotową. 
Obszar dysfunkcyjny zaburzenia charakteryzuje się osobowością powierzchownie ujawniającą swoje emocje, a skrywającą głębsze. Cechują ją pogodne usposobienie; pozorna otwartość; dynamiczność; tłumienie agresji i wrogich uczuć; silna potrzeba społecznej aprobaty, nawet za cenę nieujawniania i wyrażania swojego zdania, konformizm, postawa formalna, pewna sztywność; podwyższona skala nastawień obronnych. Osoby takie maja silną potrzebę przedstawiania się w jak najlepszym świetle, przez co wyniki testu mają niską wiarygodność, ukrywają one prawdziwe motywacje postępowania, są nieszczere i niewiarygodne w wypowiedziach - przekształcają fakty i zmieniają rzeczywistość w celu osiągnięcia własnych korzyści, kłamią, by przedstawić siebie z korzystnej strony (Akta SBDT 36/P/11, 52/P/10, 47/P/14).

Zaburzenie osobowości z pogranicza - borderline 301.83 (F 60.30) - jest charakterystyczne w grupie dramatyczno-niekonsekwentnej. Metaforyczne określenie osobowości: „Będę bardzo zła, jeśli spróbujesz mnie opuścić” (Cześnikiewicz, s. 399).

Biegli zdiagnozowali zaburzenie osobowości z pogranicza bez innych współistniejących zaburzeń.

W etiologii wskazany w sprawach jest wyłącznie okres pojawienia się zaburzenia - to wczesna dorosłość, okres przed 20. rokiem życia (Akta SBDT 48P/10, 41/P/12).

Biegli wyróżnili bardzo szeroką dysfunkcyjność zaburzenia. W sprawie (Akta SBDT 48/P/10) biegły opisuje specyficzne cechy dla osobowości borderline:

- impulsywność w obszarze seksualnym i emocjonalnym;

- impulsywność w zakresie nadużywania alkoholu i zażywania narkotyków, a także w zakresie kontaktów interpersonalnych - pozwana potrafiła godzinami rozmawiać na portalach, przez telefon ze znajomymi, spędzała wiele godzin na tzw. imprezach, wyjściach, spotkaniach z innymi, pozwana wagarowała w szkole, a także powtarzała klasę;

- niestabilność w relacjach interpersonalnych, wyborach, decyzjach cechująca się szybkimi zmianami pomiędzy skrajną idealizacją a dewaluacją;

- zaburzenie tożsamości własnej - niestabilne wyobrażenie na temat swojego ,ja”;

- niestabilność nastroju: od stanów depresyjnych z myślami samobójczymi, lękowymi, po stany uniesienia, egzaltacji, sztucznego poczucia szczęścia,

- poczucie pustki, nudy, wiecznej tęsknoty za czymś nieuchwytnym, nierealnym.

Obszar dysfunkcyjny tych osób, jak wykazują biegli, to promiskuityzm (Akta SBDT 12/P/11), kontakty z wieloma mężczyznami w trakcie pozostawania 
w związku z powodem, kontakty seksualne pozbawione więzi uczuciowych, podejmowane z przypadkowymi, zmienianymi partnerami, oraz nieumiejętność utrzymania trwałych związków (Akta SBDT 41/P/12). Ilustracja zjawiska na tym przykładzie wskazuje na inne zachowania towarzyszące zaburzeniu: używanie kłamstwa, oszustwa w celu zdobycia profitów materialnych, własnej wygody i przyjemności; manipulacja innymi poprzez histerię, szantaż emocjonalny, grożenie, wyzwiska, obrażanie innych (pozwana, aby osiągnąć swój cel, potrafiła szantażować partnera samobójstwem, by zatrzymać go przy sobie - podcinała sobie żyły, truła się tabletkami, chciała się utopić); pozwana histeryzowała, płakała, wyzywała, bywała wulgarna jak dziecko, które w niedojrzały sposób chce osiągnąć swoje cele; agresja i autoagresja (Akta SBDT 29/P/14).

Narcystyczne zaburzenie osobowości 301.81 (F 60.81) jest następnym sztandarowym przedstawicielem grupy B. Metaforycznie osobowość określana jest jako: „Mój rozkaz jest twoim życzeniem” (Cześnikiewicz, s. 407).

W sprawach biegli łączyli u diagnozowanych osobowość narcystyczną z elementami osobowości dyssocjalnej (Akta SBDT 12/P/08, 8/P/11), osobowością zależną (Akta SBDT 22/P/11; 3/P/12, 11/P/11), osobowością niedojrzałą (Akta SBDT 5/P/10, 14/P/12, 20/P/09, 44/P/11, 3/P/10, 25/P/11), cechami osobowości zależnej (Akta SBDT 12/P/13, 41/P/14), osobowością histrioniczną (Akta SBDT 16/P/14).

W etiologii zaburzenia biegli wskazują na symbiotyczny związek - zwłaszcza z matką (Akta SBDT 44/P/11, 64/P/09). Zaburzenie osobowości pozwanego istnieje od wczesnej dorosłości - okresu przed 18. rokiem życia. Matka stworzyła z nim symbiotyczny związek - polegający na spełnianiu jego oczekiwań i traktowaniu go jako kogoś wyjątkowego (Akta SBDT 5/P/13). Rodzina pierwotna wywiera silny wpływ na powstanie zaburzenia. O czym świadczą akta kolejnej sprawy: matka pozwanej była dominująca, histeryzująca, o cechach osobowości narcystycznej, traktowała ojca pozwanej z góry, w rodzinie tej panował matriarchat. Pozwana przejęła niewłaściwe wzorce zachowań po matce. Obraz rodzinny klaruje się jako niestabilny pod względem emocjonalnym. W domu tym najprawdopodobniej dochodziło do wielu kłótni, a dzieci zawierały okresowe „koalicje” z jednym z rodziców. Taki przekaz psychologiczny ze strony rodziców („nie możesz być sobą”, „bądź taki, jaki chcemy, byś był”) w formie m.in. niewypowiedzianego skryptu jest najczęściej podwaliną wtórnych zaburzeń narcystycznych (Akta SBDT 12/P/13).

Biegły wyszczególnia obszary zaburzonego funkcjonowania: brak inicjatywy w obszarze zawodowym, podejmowania decyzji, kłamstwo, oszukiwanie, manipulacja, wykorzystywanie innych w sprawach finansowych, bierność i zachowania 
ucieczkowe w wyborach życiowych, wielkościowe poczucie ja, egocentryzm i nieadekwatna ocena siebie, tendencja do postrzegania i ukazywania siebie w lepszym świetle przy wyraźnej skłonności do obwiniania innych; trudności w identyfikowaniu się z potrzebami i uczuciami innych ludzi; egoizm i egocentryzm; zawiść i butne postawy zachowania się wobec innych; impulsywność w nawiązywaniu kontaktów z płcią przeciwną; brak odpowiedzialności, obmawianie, histeria, gdy sprawy nie są zgodne z zamiarem, agresja słowna, karanie milczeniem, brak dialogu z małżonkiem (Akta SBDT 52/P/10, 5/P/13, 58/P/13). Pojawiają się również problemy z kontrolą wrogości, podejrzliwość, obmawianie innych, egoizm, kłamstwo, egocentryzm, obrażanie się, złośliwość (Akta SBDT 49/P/11), brak wglądu w siebie (Akta SBDT 53/P/14, 22/P/11), nieprzyjmowanie perspektywy innej niż własna, oczekiwanie od otoczenia przyjmowania zaspokajania własnych potrzeb (Akta SBDT 64/P/09). Kolejne cechy to: zaborczość, brak odpowiedzialności za rodzinę, niewierność seksualna (Akta SBDT 11/P/11, 14/P/11), oszukiwanie w celu osiągnięcia osobistej korzyści poprzez stosowanie szantażu, poczucia wyższości, amoralność, zazdrość (Akta SBDT 20/P/09); kradzież, malwersacje, oszustwa; przemoc psychiczna; poczucie, że wszystko mu/jej się należy i że inni muszą automatycznie spełniać jego/jej oczekiwania; poczucie wyjątkowości, mania wielkości; egoizm i brak empatii; używanie kłamstwa, mitomania, aby osiągnąć swoje cele i wykorzystać innych finansowo; niezdolność do odpowiedzialności za czyny w sferze zawodowej i zobowiązań urzędowych (Akta SBDT 35/P/13, 12/P/13, 16/P/14).

W perspektywie małżeństwa można wyróżnić dysfunkcjonalność w obszarach (Akta SBDT 3/P/10):

- wzajemności małżonków (strona pozwana po dwóch miesiącach od zawarcia małżeństwa całkowicie odsunęła się emocjonalnie od powódki - kontrahent nie dbał o jej uczucia, spędzał czas sam bądź z kochanką; oszukiwał powódkę, udawał przy innych dobrego i troskliwego męża, a przy powódce był oschły, bez kontaktu emocjonalnego z nią, nieobecny, pozwany nie angażował się również w prace domowe);

- otwarcia na nowe życie (pozwany nie wykluczał posiadania potomstwa w związku, ale nie był zaangażowany w planowanie powiększania rodziny, nie zależało mu na tym);

- wierności (pozwany nie zachował obowiązku wierności w małżeństwie zdrada nastąpiła jeszcze w narzeczeństwie, a także w małżeństwie; pozwany miał dwa związki seksualne, do których przyznał się powódce, świadkowie również potwierdzają te zdrady - zdradził w 8. roku związku przedślubnego stron, potem podczas wieczoru panieńskiego, a po ślubie był w trwałym związku z kochanką. Pozwany prowadził podwójne życie). 
Biegli podkreślają również dysfunkcjonalność osobowości narcystycznej w obszarze życia seksualnego (Akta SBDT 1/P/14), zaspakajanie wyłącznie własnych potrzeb seksualnych, nie licząc się z potrzebami partnera we współżyciu seksualnym (masturbacja, oglądanie pornografii, zmuszanie powódki do naśladowania zachowań z filmów pornograficznych).

Ostatnią jednostką w prezentowanym podziale są zaburzenia osobowości typ C - zaburzenia obawowo-lękowe. W jej skład wchodzi zaburzenie osobowości unikowej 301.82 (F 60.6). Metaforyczne określenie osobowości: „Chcę, żebyś mnie wreszcie polubił, ale wiem, że mnie nienawidzisz” (Cześnikiewicz, s. 404).

Zaburzenie unikowe osobowości współwystępuje z uzależnieniem od hazardu, nerwicą lękową (Akta SBDT 44/P/09, 28/P/14), z osobowością schizoidalno-unikową, schizotypową, z osobowością niedojrzałą (Akta SBDT 25/P/11, 38/P/11, 19/P/12)

Etiologicznie biegły upatruje związek ukształtowania się osobowości z zaburzoną relacją z ojcem, której podłożem był lęk przed ojcem (Akta SBDT 47/P/09). Biegły opisuje także uzależnienie pozwanego od ojca w wymiarze emocjonalnym. Pozwany był w okresie zawierania małżeństwa uzależniony. Badania wykazały, iż nadal jest uzależniony: pozwany boi się ojca; w młodości został przez niego wychowany przez „tresurę emocjonalną”.

Biegły sądowy, który dysponował aktami sprawy oraz wywiadem, w obszarze dysfunkcyjnym doszedł do następujących wniosków - sposobem pozwanego na życie bez zobowiązań było wchodzenie w związki z kobietami i obarczenie tych kobiet i ich rodzin zobowiązaniami finansowymi. Mowa o pierwszej cywilnej żonie, powódce, kolejnej kobiecie i obecnej - matce dziecka pozwanego. Istotne jest to, że pozwany kończył pierwszy związek i wchodził w następny bez dłuższego czasu na poznanie się i zawiązanie wspólnoty. W związek z powódką wszedł, będąc jeszcze mężem pierwszej żony, ponadto zataił ten fakt przed powódką na początku ich znajomości. Pozwany nie powiedział także podczas spisywania protokołu przedślubnego, że jest po rozwodzie cywilnym, ale podał, że jest kawalerem (Akta SBDT 38/P/11).

Zaburzenie osobowości zależnej 301.6 (F 60.7) jest znamiennym w grupie C. Metaforyczne określenie osobowości: „Chroń mnie i opiekuj się mną” (Cześnikiewicz, s. 403).

W pięciu przypadkach wykazano zaburzenie osobowości zależnej bez współistniejącej przyczyny, w pozostałych zaburzenie osobowości zależnej było połączone z osobowością narcystyczną (Akta SBDT 12/P/08, 19/P/15), z niedojrzałością (Akta SBDT 12/P/08, 31/P/12, 41/P/13, 28/P/13, 12/P/13, 64/P/14), z osobowością obsesyjno-kompulsywną (Akta SBDT 618/P/14), z obniżeniem ilorazu inteligencji 
(Akta SBDT 4/P/15) oraz, na co warto zwrócić uwagę, z uzależnieniem (Akta SBDT 8/P/14) od pornografii, gier komputerowych i narkotyków.

W kwestii etiologicznej opinie skupiają się na sytuacji rodzinnej, wychowawczej (Akta SBDT 31/P/12). Biegły sądowy tak charakteryzuje rodzinę pochodzenia osoby z zaburzeniem: „Matka była silną osobowością - narzucała swoje zdanie synowi i nadmiernie skupiała się na jego życiu”. Matka implikowała swoje zdanie i podejmowała decyzje za pozwanego. W kształtowaniu osobowości zależnej znaczenie ma istnienie przyczyny psychicznej w postaci osobowości bierno-zależnej (silne związanie emocjonalne z matką), symbiotyczne związanie z rodzicami (Akta SBDT 18/P/14). Mężczyzna często uzależniony jest od rodziny pierwotnej, a szczególnie swojego ojca. Emocjonalnie związany ze swoją rodziną pierwotną szczególnie mocno pozostawał pod wpływem ojca. Jako dziecko był bity i zastraszany przez niego. Ojciec pozwanego był dominatorem - rozporządzał innymi w domu, a gdy mu się przeciwstawiali, straszył agresją fizyczną. Jako dorosły mężczyzna musiał ścielić na żądanie ojca łóżko rodzicom, a także musiał być w domu o tej godzinie, o której ojciec sobie życzył (Akta SBDT 15/P/13, 12/P/13).

Na kształtowanie się osobowości zależnej ma również wpływ poziomu inteligencji (Akta SBDT 51/P/14). Powołany w sprawie biegły sądowy stwierdził u pozwanej w chwili zawierania małżeństwa obniżony iloraz inteligencji (odpowiadający wiekowi 12 lat).

Decydują o tym również przeżycia z dzieciństwa, także o charakterze odrzucającym (Akta SBDT 64/P/14). Biegły sądowy stwierdził: „Przeżycia z dzieciństwa (presja psychiczna, a także szantaż psychiczny ze strony matki, agresja fizyczna ojca wobec powódki - szarpanie, popychanie) wpłynęły na ukształtowanie się osobowości z kręgu lękowych - powódka charakteryzowała się w dniu ślubu osobowością lękową - nerwica lękowa z elementami depresji”. Powódka była pod silnym wpływem swojej matki od wczesnych lat dziecinnych - była uzależniona od matki w sensie psychoemocjonalnym - matka wywierała wpływ na powódkę w decyzjach i zachowaniu.

Powołany w sprawie biegły sądowy opisuje obszar dysfunkcyjny w następujący sposób: „Kontrahent nie potrafi podejmować samodzielnie decyzji bez porady i nakierowania ze strony innych: radził się we wszystkich sprawach życiowych swojej matki (decyzja o małżeństwie, o zatajeniu swoich kredytów przed powódką, decyzja o powrocie do powódki po rozstaniu - motorem tych działań była matka pozwanego)”. Również powódka pełniła po ślubie funkcję osoby decydującej za pozwanego (spłacanie kredytów, płacenie wezwań, rachunków, dotrzymywanie zobowiązań, inicjatywa w remontowaniu, meblowaniu domu). Osobowość zależną cechują: labilność emocjonalna - od furii, agresji słownej i fizycznej po uległość 
i dostosowanie się do innych; niedojrzałe mechanizmy budowania relacji z innymi; brak właściwej samooceny - samoocena rozchwiana; budowanie swojej wartości kosztem innych, nadwrażliwość na odrzucenie i ocenę własnej osoby przez innych; napięcie, roztrzęsienie, kontrola; nieufność i ostrożność w relacjach; introwersja społeczna; wyobcowanie od samej siebie; skrajnie niska samoocena, epizody depresji z objawami płaczliwości, braku sił, anhedonia; problemy podczas współżycia - zacisk pochwy, napięcie, lęk, trudności z przeżywaniem satysfakcji seksualnej. Małżeństwo jest swoistym trójkątem z udziałem rodzica (Akta SBDT 48/P/13, 6/P/13, 17/P/12).

Kontrahent musiał być kierowany odnośnie do tego, co ma w życiu robić, jak postępować, szczególnie w istotnych kwestiach życiowych, a sam jedynie decydował o błahych sprawach. Potrzebował innych, by wzięli odpowiedzialność za większość obszarów jego życia - utrzymywali go podczas studiów (rodzice, małżonek, dziadkowie). Wykazywał się niezdolnością do wyrażania innego zdania, łatwo było nim manipulować i kierować. Używał kłamstwa wtedy, gdy było to wygodne, w celu manipulacji innymi dla swoich korzyści finansowych i emocjonalnych. Do obszaru dysfunkcyjnego należą również: lenistwo i zrzucanie odpowiedzialności na innych w głównych obszarach swojego życia; niskie poczucie wartości objawiające się zamknięciem w sobie, trudnościami z wyrażaniem emocji, własnego zdania, życie z dnia na dzień, związywanie się z kobietami zaradnymi i przedsiębiorczymi; omawianie wszystkich spraw rodzinnych z rodzicami, z matką (Akta SBDT 20/P/11, 16/P/12); trudności w budowaniu dojrzałych relacji, uzależnienie od świata wirtualnego, małomówność, nieufność (Akta SBDT 8/P/14); znaczna niedojrzałość emocjonalna w sposobie zachowywania się i traktowania innych; umiejętność szybkiego znajdowania źródła oparcia i opieki, gdy kończy się wcześniejsza relacja; trudności z budowaniem szczerej, bliskiej więzi - opartej na odpowiedzialności ze swojej strony i inicjatywnie w kontaktach, a zamiast tego bierność, uległość, brak inicjatywy; potrzeba opieki i wsparcia, sterowanie życiem i wyborami, nieumiejętność przeciwstawiania się osobom (Akta SBDT 41/P/13, 15/P/14). W relacjach z silnymi osobowościami osoba taka zachowuje się intrapunitywnie - karze siebie i nadmiernie bierze na siebie winę tam, gdzie jej nie ma. Ponadto wnioski główne biegłego zostają wzmocnione poprzez ujawnione w teście cechy pozwanego (procentowo znaczące): dążenie do zakłamania prawdziwego profilu osobowości, nastawienie obronne, słabe ego, ukryte i nieuświadomione stany depresyjne, silna potrzeba aprobaty społecznej, tłumienie prawdziwych potrzeb i uczuć, lęki społeczne, tłumienie agresji, stanów napięcia, niepokoju i nerwowości. Towarzyszy im również zachowanie submisyjne (Akta SBDT 24/P/14). Wahania między zachowaniami poddania się, zbuntowania, niedojrzałość, brak 
odpowiedzialności za swoje wybory, zachowania, nieufność i ostrożność w relacjach - trudności z otwieraniem się, potrzeba społecznej aprobaty.

Ostatnim zaburzeniem w spektrum C jest obsesyjno-kompulsyjne zaburzenie osobowości 301.4 (F 60.5). Metaforyczne określenie osobowości: „Po prostu nie chce popełnić błędu” (Cześnikiewicz, s. 406).

W rozpoznaniu różnicowym łączono zaburzenie obsesyjno-kompulsywne z osobowością zależną (Akta SBDT 7/ - P/11), z histrioniczną (Akta SBDT 48/P/12, 49/P/11), niedojrzałą w stopniu znacznym (Akta SBDT 51/P/12, 24/P/12) i homoseksualizmem (Akta SBDT 32/P/13).

Żaden z biegłych nie określa w analizowanych sprawach pochodzenia etiologicznego osobowości obsesyjno-kompulsywnej.

Obszar dysfunkcjonalności wykazany przez biegłych to: brak kompromisowości (Akta SBDT 51/P/12) - pozwany przez swoją niedojrzałość psychiczną nie był w stanie panować i kontrolować swoich emocji, a także właściwie wyrażać swoich potrzeb i zdania. Stosował wobec powódki skrajnie niedojrzałe mechanizmy: obrażanie się, wulgarne poniżanie powódki, szantaż emocjonalny - straszył, że popełni samobójstwo, a także posunął się do przemocy fizycznej. Pozwany nie był zdolny do kompromisu (Akta SBDT 36/P/12). Cechy osobowości kontrahentów obsesyjno-kompulsywnych: skoncentrowanie na sobie; tłumienie uczucia, odpowiedzialność społeczna i zawodowa; nastawienie na działanie i rywalizację; bezkompromisowość; nieznaczny lęk społeczny powodujący niepodejrzliwość i nieufność w relacjach; odreagowanie lęków, trudnych emocji na stronie przeciwnej, zatracanie się i skupianie na obowiązkach zawodowych (Akta SBDT 28/P/13); unikanie współżycia (Akta SBDT 32/P/13). Powołany w sprawie biegły sądowy stwierdził u pozwanego unikanie współżycia seksualnego, oziębłość seksualną, której pochodzenie może wynikać z ukrytych skłonności homoseksualnych lub zaburzonej osobowości o charakterze obsesyjno-kompulsywnym. Biegły nie stwierdza wyraźnie, z jakiego źródła pochodzi oziębłość, lecz daje alternatywę albo spowodował ją pierwszy wymieniony wyżej czynnik, albo drugi. Zebrane dowody skłaniają sędziów ku przekonaniu, że oziębłość jako przyczyna psychiczna miała związek z osobowością obsesyjno-kompulsywną.

\section{ZAKOŃCZENIE}

Przegląd zaburzeń osobowości w oparciu o akta sprawy SBDT pozwolił na wskazanie stanu faktycznego i doprecyzowanie pojemnego sformułowania defektu psychicznego w przypadku kan. 1095 n. 1 i 2 KPK oraz przyczyny natury psychicznej 
kan.1095 n. 3 KPK zdefiniowanych w DSM (Diagnostic and Statistical Manual of Mental Disorders) i ICD -10 (Klasyfikacja zaburzeń psychicznych i zaburzeń zachowania). Samo wyszczególnienie zaburzeń osobowości byłoby mało pomocne dla biegłych i sędziów, gdyby nie wskazanie na różnicowość, która poszerza zakres przyczyny psychicznej, etiologie, która wskazuje na obecność zaburzenia w chwili wyrażania zgody na małżeństwo, jak również obszar dysfunkcyjny, który odnosi się do niemożności realizowania istotnych obowiązków małżeńskich. Warto nadmienić, że wyszczególnione procesy sądowe, które obejmowały sprawy natury psychicznej, dotyczyły 94 kobiet i 62 mężczyzn. W 122 sprawach sędziowie stwierdzili nieważność małżeństwa, w 36 opowiedzieli się za jego ważnością.

Powyższa publikacja, która odnosi się do małżeństwa kanonicznego, ma również odniesienie do małżeństw zawartych poza kanonicznym porządkiem prawnym i może być pomocą dla psychologów prowadzących terapie małżeńskie. Do zawarcia małżeństwa według prawa kanonicznego, wymagana jest zdolność prawna i naturalna. Zdolność prawną posiadają wszyscy pełnoletni, którzy mają zdolność do czynności prawnych. Natomiast zdolność naturalna odnosi się do psychiki i osobowości człowieka, co stanowi zakres zainteresowania psychiatrii i psychologii. Zarówno w porządku kanonicznym, jak i poza nim zdolność naturalna ma takie samo znaczenie dla trwałości i rozwoju małżeństwa. Jeżeli osoba obarczona dysfunkcjami w obrębie zdolności naturalnej zawiera małżeństwo, może okazać się, że trwanie w takim związku jest niemożliwe lub wymaga terapii z powodu wymienionych wyżej przyczyn czyniących jedną ze stron małżeństwa niezdolną do stworzenia wspólnoty małżeńskiej. Z tego właśnie powodu przedstawione powyżej ustalenia mogą okazać się przydatne dla specjalistów zajmujących się rodziną i małżeństwem.

\section{Bibliografia}

Amati, A. (2009). L'immaturita' psico-affettiva e matrimonio canonico (can.1095, 2-3 CIC). Watykan: Libreria Editrice Vaticana.

Chiappetta, L. (1990). Il matrimonio nella nuova legislazione canonica e concordataria. Roma: Edizioni dehoniane.

Cześnikiewicz, A. (2017). Zaburzenia osobowości i zachowania u dorosłych. W: M. Jarema (red.), Psychiatria. Warszawa: PZWL.

Erlebach, G. (2004). Le allocuzioni dei sommi pontefici alla Rota Romana.. Watykan: Libreria Editrice Vaticana.

Gałecki, P., Pilecki, M., Romaszewska, J., Szulc, A., Sidorowicz, S., Wciórka, J. (2018). Kryteria diagnostyczne zaburzeń psychicznych DSM-5. Wrocław: Edra Urban \& Partner. 
Góralski, W. (1996). Niezdolność do zawarcia małżeństwa według kan. 1095 nn. 1-3 KPK. Próba syntezy. Prawo Kanoniczne, 39(3-4).

Majer, P. (2011). Kodeks Prawa Kanonicznego. Komentarz. Kraków: Wolters Kluwer Polska.

Sprawy o stwierdzenie nieważności małżeństwa Sądu Biskupiego Diecezji Toruńskiej-SBDT (sygn. Akt): 33/P/10, 57/P/08, 63/P/09, 46/P/08, 52/P/10, 1/r /11, 61/P/06, 50/P/10, 34/P/11, 18/P/11, 44/P/09, 8/P/11, 21/P/11, 2/r P/11, 12/P/08, 48/P/10, 10/P/12, 9/P/12, 22/P/11, 13/P/11, 64/P/09, 35/P/11, 4/P/12, 4/P/10, 53/P/12, 25/P/10, 26/P/11, 12/P/11, 36/P/10, 29/P/11, 13/P/13, 2/r /11, 5/P/10, 46/P/11, 28/P/12, 14/P/11, 49/P/12, 10/P/11, 79/P/06, 23/P/12, 11/P/12, 41/P/12, 9/P/13, 36/P/11, 17/P/12, 39/P/11, 37/P/12, 21/P/12, 47/P/09, 20/P/09, 13/P/12, 33/P/11, 29/P/12, 48/P/12, 40/P/10, 34/P/12, 20/P/11, 32/P/12, 11/r/12, 12/r/13, 44/P/11, 3/P/10, 52/P/12, 7/P/13, 51/P/12, 32/P/12, 50/P/13, 25/P/11, 11/P/13, 52/P/13, 24/P/12, 31/P/12, 40/P/12, 4/P/13, 22/P/13, 2/P/13, 54/P/12, 8/P/14, 51/P/13, 5/P/13, 5/P/12, 25/P/12, 37/P/11, 41/P/12, 1/P/13, 59/P/13, 58/P/13, 1/P/14, 36/P/12, 43/P/13, 49/P/10, 42/P/11, 49/P/14, 36/P/13, 30/P/13, 41/P/13, 46/P/12, 28/P/13, 54/P/13, 35/P/13, 49/P/11, 18/P/14, 15/P/13, 7/P/12, 38/P/11, 19/P/12, 26/P/13, 48/P/13, 2/P/12, 12/P/13, 15/P/14, 22/P/12, 2/P/14, 25/P/14, 45/P/12, 6/P/13, 38/P/14, 51/P/14, 45/P/13, 7/P/14, 9/P/14, 60/P/13, 55/P/13, 47/P/13, 20/P/14, 19/P/14, 14/P/14, 10/P/14, 14 r1/14, 17/P/14, 33/P/13, 6/P/11, 4/P/15, 18/P/15, 53/P/14, 29/P/14, 37/P/14, 32/P/13, 3/P/13, 40/P/13, 34/P/13, 32/P/14, 47/P/14, 26/P/14, 22/P/14, 30/P/14, 34/P/14, 36/P/14, 33/P/14, 43/P/14, 20/P/12, 24/P/14, 45/P/14, 59/P/14, 62/P/14, 64/P/14, 28/P/14, 13/P/15, 4/P/14, 44/P/14, 16/P/14, 39/P/15.

Wciórka, J., Pużyński, S. (red.). (1998). Klasyfikacja zaburzeń psychicznych i zaburzeń zachowania w ICD-10. Badawcze kryteria diagnostyczne. Kraków-Warszawa: Uniwersyteckie Wydawnictwo Medyczna „Vesalius”, Instytut Psychiatrii i Neurologii.

Zuanazzi, G (2013). Psicologia e Psichiatria nelle cause matrimoniali canoniche. Watykan: Libreria Editrice Vaticana. 